\title{
IMPROVING LANGUAGE POLITENESS OF DYAH GALIH AGUNG SENIOR AND JUNIOR HIGH SCHOOL STUDENTS
}

\author{
${ }^{1 *}$ Rahmadsyah Rangkuti and ${ }^{2}$ Zulfan \\ ${ }^{1}$ Department of English, University of Sumatera Utara, Medan, Indonesia \\ ${ }^{2}$ Department of English, Sekolah Tinggi Bahasa Asing Institut Teknologi Manajemen \\ Indonesia, Medan, Indonesia \\ *Corresponding author: rangkuti@usu.ac.id
}

\begin{abstract}
This article analyzes the strategy for language politeness of Dyah Galih Agung Senior and Junior High School students, Deli Serdang District, which is realized through the use of speech acts. Every speaker should have knowledge on language politeness. Pragmatically speaking, language politeness is related and realized in speech acts. Speakers should understand speech contexts of their utterance and meanings contained in it. Some utterances may hurt the listeners but with choosing and using proper dictions and applying politeness, it will not hurt the listeners. The data collected using observation and conversation method (Sudaryanto, 2017) and then analyzed using Searle's speech act theory (1979) and Leech's politeness principles (2014). The findings show that the students in Dyah Galih Agung Senior and Junior High School, Deli Serdang District, use assertive, directive, commissive, and expressive speech act. Regarding the strategy for language politeness, the students use direct speech act more than indirect one which is influenced by the close social relationship among them. The findings also show that the application of Leech's politeness strategy (2014) is able to improve the students' language politeness ability.
\end{abstract}

Keywords: speech act, illocution, politeness

\section{Introduction}

Language skill a student has to master as the indicator of the student's language ability consists of four skills; speaking, listening, reading, and writing (Widdowson, 1996: 57). Speaking is the most highlighted skill since in general, social interaction in daily life is mostly dominated by verbal language than nonverbal language.

In order to be skilled in speaking, a student has to master grammar and has adequate vocabulary. Besides these two points, a language learner, according to Thornbury (1989: 11), has to be aware of the context of the conversation in order for the message to be understood by the hearer. He further explained that it is important for either a language teacher or a learner to know the relationship between language and politeness. In other words, a student has to have the knowledge about language 
politeness. Language politeness is always related with the use of speech act. According to Siregar (2011: 97), this is because in using a speech act, a speaker naturally intends to create and maintain a certain relationship between the speaker itself and the hearer besides expressing intention and wish. In this article, the discussed topic is about the use of illocutionary act consisting of assertives, directives, commissives, expressives, and declarations based on pragmatic perspective. In pragmatic study, the use of such speech acts is always related with politeness (refer to Leech, 1983: 16; Tarigan, 1994: 49).

There are four reasons of why it is important to conduct this research. Firstly, it is conducted in order to establish a polite character and personality in a student since early age (refer to, Pranowo, 2009: 1; Sibarani, 2015: 124;). A language teaching with pragmatic approach means teaching a student to use language for communication by considering the context (Purwo 1990: 30-31). The context here is understood as the shared background knowledge owned by the speaker and the hearer so that the hearer can understand what the speaker means. (refer to Leech, 1983: 13; Cruse, 2006: 35; Kridalaksana, 2008, 134; Holmes \& Stubbe, 2015: 9).

Secondly, the phenomena of violence in education field especially in schools have reached an alarming level (Sari \& Agung, 2015). Young generation and children have been experiencing degradation of language politeness (refer to Kusno, 2014). According to Baryadi (2012: 33), impoliteness in speech tends to be the representation of verbal abuse. Such act could lead to bullying behavior (refer to Suprihatin, 2012). Based on these phenomena, this research is conducted as one of the solutions in preventing the increasing number of verbal abuse among students.

Thirdly, the use of language politeness has not been getting much attention. This happens because a language user does not find out yet that there is a structure of politeness in language structure (Pranowo, 2009: 4). Furthermore, Pranowo explained that a polite language structure is a language structure arranged by the speaker so that it does not sound offensive to the hearer. Fourthly, this research is conducted to support government program in carrying out the curriculum 2013 which includes core competencies and basic competencies about language politeness (Kemendikbud, 2013: 6-8).

\section{Literature Review}

The existence of context in pragmatics study is crucial since it helps to interpret the speaker's intention. According to Leech (1983: 13), context is the things related to all physical aspects and social settings relevant to the speech. In short, context in pragmatics is all the shared knowledge background owned by the speaker and the hearer so that the hearer can interpret the speaker's speech.

Furthermore, Leech (1983: 13) stated that there are some other aspects one should be aware of in studying the use of language based on pragmatic view, which includes speaker and hearer, purpose of speech, speech as an act or activity, and speech as a product of verbal act. 
There are several discussions related with pragmatics, they are deixis, implicature, presupposition, speech act, politeness, and conversation analysis (Levinson, 1983: 27; Baker \& Ellece, 2011: 100).

\section{Politeness}

According to Leech (2014: 3), language politeness is the form of communicative behavior which is influenced by sociocultural factor in a certain society. What is called language politeness, as Leech said, is when the speaker gives favor/benefit not only to himself but also the hearer and the third party whether the third party is present or not in the speech situation. This time, he symbolized the speaker by $\mathrm{S}$ (self) and the hearer and the third party by $\mathrm{O}$ (other).

Regarding this matter, Leech (2014: 87-88) stated that the purpose of polite conversation is to avoid conflict in a communication. In other words, communicative concord is the main goal of polite language. For one to be said having a polite language, one should show politeness in using language.

As Leech said (2014: 89), to have a communicative concord, the speaker should pay attention to and consider the conformity between social purpose (to maintain harmony) and illocutionary purpose. In other words, to attain the concordance of communication, illocutionary purpose should be in accordance with social purpose.

Based on this, to devise a strategy for illocution of asking and criticizing, for example, whose purpose is not in accordance with social purpose, the speaker could use negpoliteness strategy. It is a politeness strategy that could be used by the speaker by decreasing or weakening the negative expression toward the hearer. Neg-politeness includes indirectness, hedging, and understatement. Meanwhile, to maximize the politeness impression, the speaker could use pos-politeness strategy by adding or strengthening the expression that gives positive values to the hearer.

Based on the two politeness strategy above, Leech developed what he called General Strategy of Politeness (GSP). It is a model of politeness strategy which consists of ten politeness maxims. By utilizing this strategy, the speaker could avoid discord with the hearer. The maxims are:

Table 1. Politeness Maxims in General Strategy of Politeness

\begin{tabular}{|c|c|c|c|}
\hline $\begin{array}{c}\text { Maxim } \\
\text { (expressed with imperative mood) }\end{array}$ & $\begin{array}{c}\text { Relationship } \\
\text { between } \\
\text { Two Maxims }\end{array}$ & Maxims & Types of Speech Act \\
\hline (M1) maximize the value of desire to other & \multirow{2}{*}{$\begin{array}{l}\text { Generosity, } \\
\text { Wisdom }\end{array}$} & Generosity & Commissive \\
\hline (M2) minimize the value of desire to self & & Wisdom & Directive \\
\hline (M3) maximize the value of quality to other & \multirow{2}{*}{$\begin{array}{l}\text { Praise, } \\
\text { Modesty }\end{array}$} & Praise & Praise/Greeting \\
\hline (M4) minimize the value of quality to self & & Modesty & Self-devaluation \\
\hline $\begin{array}{l}\text { (M5) maximize the value of obligation to } \\
\text { other }\end{array}$ & \multirow[t]{2}{*}{ Obligation } & $\begin{array}{l}\text { Obligation (from } \\
\text { self to other) }\end{array}$ & Apologizing, thanking \\
\hline (M6) minimize the value of obligation to self & & $\begin{array}{l}\text { Obligation (from } \\
\text { other to self) }\end{array}$ & $\begin{array}{l}\text { Response to gratitude } \\
\text { and apology }\end{array}$ \\
\hline (M7) maximize the value of opinion to other & \multirow[t]{2}{*}{ Opinion } & Agreement & Agreeing, disagreeing \\
\hline (M8) minimize the value of opinion to self & & Opinion reticence & Giving opinion \\
\hline
\end{tabular}


Proceedings of the $1^{\text {st }}$ Annual International Conference on Language and Literature, 18-19 April 2018, Fakultas Sastra, UISU, Medan, Indonesia.

\begin{tabular}{|l|l|l|l|}
\hline $\begin{array}{l}\text { (M9) maximize the value of sentiment to } \\
\text { other }\end{array}$ & Sentiment & Symphaty & $\begin{array}{l}\text { Congratulating, } \\
\text { sympathizing }\end{array}$ \\
\cline { 1 - 1 } $\begin{array}{l}\text { (M10) minimize the value of sentiment to } \\
\text { self }\end{array}$ & & Feeling reticence & Holding sentiment \\
\cline { 2 - 4 }
\end{tabular}

\section{Research Method}

This research applies Classroom Action Research. According to Kemmis (in Sani and Sudirman, 2012: 8), classroom action research is a form of reflective inquiry conducted in partnership by teachers into a certain social situation (including education) in order to restore the rationality, validity, and legality of (a) educational social practices done by the teachers themselves, (b) their understanding of dealing with the practices, and (c) institutional situation of the place where the education is carried out. Meanwhile, Ebbut (in Wiriaatmadja, 2008:12) mentioned that classroom action research is a systematic study about the efforts in restoring the practice of education done by a group of teachers by making acts in learning process which is based on their reflection of the result of those acts. The technique of data analysis is a plot model which includes data reduction, data presentation, and drawing conclusion.

\section{Results and Discussion}

The realization of illocutionary act of Dyah Galih Agung Senior and Junior High School students varies in their daily communication. Based on the analysis, there are four kinds of illocutionary act; assertives, directives, commissives, and expressives found in different contexts such as in a dormitory, canteen, public kitchen, mosque, library, or classroom.

Based on the analysis that has been conducted this far, three illocutionary acts were found, they are assertive speech, directive speech, and commissive speech. Declarative speech has not been found yet since this speech is always related with power and authority.

Some findings are presented to serve as illustration:

\section{Assertive Speech Act}

Assertive speech act is a speech act which involves the speaker in the validity of the expressed proportion, such as making statement, informing, suggesting, bragging, complaining, and reporting. The speech act of making statement, informing, emphasizing, and explaining were found during this research. Below are some of the results found. The context is a the speech of a third year senior high school during a speech practice in a classroom.

- Making statement

"It is an obligation for every Moslem woman to cover their aurat" (Eng)

"Menutup aurat itu hukumnya wajib bagi setiap muslimah". (Ind)

Context: The intention of the speech (1) is to state in front of all the students in that classroom that every Moslem woman is obliged to cover their aurat.

"Islam is beautiful, peaceful[...]. (Eng)\ 
Proceedings of the $1^{\text {st }}$ Annual International Conference on Language and Literature, 18-19 April 2018, Fakultas Sastra, UISU, Medan, Indonesia.

"Islam itu indah, damai[...]. (Ind)

Context: The intention of the speech (2) is to state in front of all the students in that classroom that Islam is a peace-loving religion.

[...]the power of Islam is in its brotherhood. (Eng)

[...]kekuatan Islam itu ada di dalam persaudaraan. (Ind)

Context: The intention of the speech (3) is to state in front of all the students in that classroom that Muslims will get stronger if they unite to keep their brotherhood.

- Informing

"Jilbab is the clothes which cover all parts of body except face and palms." (Eng)

"Jilbab adalah pakaian yang menutupi seluruh anggota tubuh kecuali wajah dan telapak tangan". (Ind)

Context: The intention of the speech (4) is to give information about the parts of body that should be covered by jilbab.

"I'll have mudifah tomorrow." (Eng)

"Besok aku mudifah" (Ind)

Context: Speech (5) is a speech by a third year high school student to a friend in front of canteen. The speaker informed that he would be visited by his parents tomorrow.

"Ustazah Dina scolded[...] (Eng)

"Ustazah Dina dah marah-marah sama[...] (Ind)

Context: Speech (6) is a speech by a third year junior high school student to a friend who returned the speaker's book late. The speaker informed the hearer that the late return caused the speaker scolded by a teacher.

"Ustazah already nagged at me[...] (Eng)

"Ustazah dah merepet-repet loh samaku[...] (Ind)

Context: Speech (7) is a speech by a third year high school student to a friend who returned a book late. The speaker informed the hearer that the late return caused the speaker nagged by a teacher.

"I'm scared of being scolded." (Eng)

"aku takut dimarahi" (Ind)

Context: Speech (8) is a speech by a third year junior high school student who intended to tell his friend that he is afraid of being scolded by his parents if he skips class.

- Emphasizing

[...] because covering aurat is a part of attendance. (Eng)

[...] karena menutup aurat adalah sebagian dari ibadah. (Ind)

Context: Speech (9) is a speech by a third year high school student during a speech practice in a classroom. The intention of the speech is to emphasize that wearing jilbab is the command from Allah s.w.t. as the form of attendance that brings us reward. 
Proceedings of the $1^{\text {st }}$ Annual International Conference on Language and Literature, 18-19 April 2018, Fakultas Sastra, UISU, Medan, Indonesia.

[...] Parents never expect us to pay back[...] (Eng)

[...] Orang tua tidak pernah berharap imbalan dari kita[...] (Ind)

Context: Speech (10) is a speech by a third year high school student during a speech practice in a classroom. The intention of the speech is to emphasize that parents never expect their children to pay anything back.

"Death comes to everyone regardless of age, young or old, social rank, poor or rich." (Eng)

"Kematian tak pandang bulu, tak pandang usia, tua maupun muda, tak pandang kasta, miskin ataupun kaya". (Ind)

Context: Speech (11) is a speech by a third year high school student during a speech practice in a classroom. The intention of the speech is to emphasize that death will come to anyone, anywhere, and anytime.

"I only have a little money left and there are many things I still want to buy." (Eng)

"Uangku tinggak sedikit, masih banyak yang mau kubeli" (Ind) Context: Speech (12) is a speech by a third year junior high school student to a friend who wanted to borrow some money. The intention of the speech is to inform that the speaker does not have enough money to lend either.

- Explaining

"Social media enables us to communicate with people regardless of distance. We can also know other important informations and share experience with our friends on social media." (Eng)

"Dengan media sosial kita bisa berkomunikasi dengan orang yang jauh dari kita.

Kita juga bisa mengetahui informasi-informasi penting lainnya. Kita juga bisa berbagi pengalaman kepada teman-teman yanga ada di media sosial". (Ind)

Context: Speech (13) is a speech by a third year high school student during a speech practice in a classroom. The intention of the speech is to explain the various kinds of functions and benefits of social media for people's life.

"Nowadays people are more afraid of the creations than the Creator." (Eng)

"Zaman sekarang orang lebih banyak takut kepada yang diciptakan dari pada kepada penciptanya". (Ind)

Context: Speech (14) is a speech by a third year high school student during a speech practice in a classroom. The intention of the speech is to explain the situation of people nowadays where they are more afraid of other people than their God.

\section{Directive Speech Act}

Directive speech act is intended for the hearer to do something, such as ordering, giving command, begging, asking, suggesting, recommending, advising. The speech act of giving command, asking, advising, persuading, forbidding, reminding, and begging were found during this research.

- Giving Command

(15) “hey, hey, come here, both of you[...] (Eng) 
Proceedings of the $1^{\text {st }}$ Annual International Conference on Language and Literature, 18-19 April 2018, Fakultas Sastra, UISU, Medan, Indonesia.

"eh, eh, sini dulu kelen dua[...] (Ind)

Context: Speech (15) is a speech by a third year senior high school student to two third year junior high school students in front of dormitory with the intention to have the two students coming.

(16) “[...]throw this garbage!" (Eng)

"[...]buang dulu sampah ini!" (Ind)

Context: Speech (16) is a speech by a third year senior high school student to two third year junior high school students in front of dormitory with the intention to have them throwing the garbage.

(17) "Get in there quickly!" (Eng)

"Cepat sana! (Ind)

Context: Speech (17) is a speech by a third year senior high school student to a third year junior high school student in front of dormitory with the intention to make the junior not come late to the class.

- Asking

(18)"Lend me your money, will you?." (Eng)

"Pinjam uangmu kenapa? (Ind)

Context: Speech (18) is a speech by a third year junior high school student intending to borrow some money from a friend in canteen.

(19)"Just give it back to me." (Eng)

"Balikin pokoknya" (Ind)

Context: Speech (19) is a speech by a third year junior high school student who asked a friend to return a book.

(20) "Where's my Social Sciences book?" (Eng)

"Mana buku IPS-ku? (Ind)

Context: Speech (20) is a speech by a third year junior high school student who asked a friend to return a book.

(21) "watch your step" (Eng)

"tengok-tengoklah kalau jalan" (Ind)

Context: Speech (21) is a speech by a third year senior high school student to a junior asking the junior to watch his steps while walking.

"Please teach me" (Eng)

"Ajari aku ya" (Ind)

Context: Speech (22) is a speech by a third year junior high school student to a friend who succeeded in presenting his homework in front of the class. The speaker wanted to ask the hearer to teach him about the homework.

"Hey, look at your rubbish" (Eng)

"Eh dek, sampah kaulah" (Ind) 
Context: Speech (23) is a speech by a third year junior high school student to a friend who intentionally threw rubbish in front of the speaker after he cleaned the dormitory. The intention is to ask the hearer to throw the rubbish in its place.

(24) "Therefore, I'd like to encourage all Moslem women to cover aurat." (Eng)

"Jadi pesan saya kepada seluruh wanita muslimah mari bersama-sama kita menutup aurat". (Ind)

Context: Speech (24) is a speech by a third year senior high school student during a speech practice in a classroom. The speaker encouraged all the students in the class to always cover their aurat.

(25) "Come on." (Eng)

"Yok lah". (Ind)

Context: Speech (25) is a speech by a third year junior high school student in front of dormitory. The speaker intended to ask a friend to buy food in the canteen together.

(26) "Let's go over there." (Eng)

"Kesana aja kita". (Ind)

Context: Speech (26) is a speech by a third year junior high school student in kitchen. The speaker intended to ask a friend to sit together on the right side of the kitchen door.

- Reminding

(27) "Remember, how big the sacrifice of parents for their children is[...]" (Eng)

"Ingat, besarnya jasa orang tua kepada anaknya[...]" (Ind)

Context: Speech (27) is a speech by a third year high school student reminding his friends to always respect their parents. The speech was delivered in a mosque after afternoon prayer.

(28) "Alright, tomorrow." (Eng)

"Betul ya, besok ya". (Ind)

Context: Speech (28) is a speech by a junior high school student in front of dormitory. The speaker intended to remind his friend to return a book tomorrow.

- Advising

(29)"[...] therefore you should pray for your parents." (Eng)

[...] makanya doakan orang tua itu". (Ind)

Context: Speech (29) is a speech by a senior high school student giving advice to a friend to always pray for his parents. The speech was delivered in a mosque after afternoon prayer.

(30) "[...] eat them all, it's a waste if you don't finish the food." (Eng)

[...] habiskan itu, mubazir kalau ada sisa". (Ind)

Context: Speech (30) is a speech by a senior high school student giving advice to a friend to finish his food. The speech was delivered in the kitchen. 
Proceedings of the $1^{\text {st }}$ Annual International Conference on Language and Literature, 18-19 April 2018, Fakultas Sastra, UISU, Medan, Indonesia.

- Forbidding

(31) “[...] don't drink while standing up [...]” (Eng)

[...] jangan minum sambil berdiri [...] (Ind)

Context: Speech (31) is a speech by a third year high school student to a first year student in the public kitchen. The speakert told the hearer not to drink while standing in line.

(32)" $[\ldots]$ don't cut in line [...] (Eng)

[...] jangan ada yang motong[...] (Ind)

Context: Speech (32) is a speech by a third year senior high school student to a third year junior high school student in the public kitchen. The speaker intended to tell the hearer not to cut in line when taking food.

- Begging

(33) "Ya Allah, maafah Sa, afwanlah" (Eng)

"Ya Allah, maafah Sa, afwanlah" (Ind)

Context: speech (33) is a speech by a third year senior high school student to a friend in front of library. The speaker begged for forgiveness from his friend because of returning a book late.

(34) “I'm sorry I'm short of money[...] (Eng)

"kak, maaf ya uang saya kurang[...]. (Ind)

Context: Speech (34) is a speech by a third year junior high school student to a vendor in canteen. The speaker intended to apologize to the vendor because it turned out that he did not have enough money to pay the food he bought.

(35) "Sorry, I only have one." (Eng)

"maaf ya, aku cuma punya satu". (Ind)

Context: Speech (35) is a speech by a third year junior high school student to a friend who asked the speaker to give something. The intention of the speech is to apologize because the speaker could not share and give what he had because he only had one of it.

\section{Commissive Speech Act}

Commissive speech act is a speech act that binds the speaker with an act that the speaker will do in the future, such as promising something, making vow, offering, praying. The speech act of promising something and offering were found during this research.

- Promising something

(36) "[...] I'll pay you back, l'll have mudifah tomorrow." (Eng)

[...] kugantilah, besok aku mudifah. (Ind)

Context: Speech (36) is a speech by a third year junior high school student to a friend when he wanted to borrow some money in front of canteen. The speaker promised to pay his friend back the next day. 
(37) "[...]alright, l'Il tell him later." (Eng)

[...] ya udah nanti kubilangi sama dia. (Ind)

Context:Speech (37) is a speech by a third year junior high school student to a friend in front of their class. The speaker promised to tell his friend who was absent to return soon the book that his friend borrowed.

(38) "Tomorrow." (Eng)

"Besoklah". (Ind)

Context: Speech (38) is a speech by a third year junior high school student to a friend in front of dormitory. The speaker intended to pay his debt tomorrow.

(39)"[...] I'Il pay you back when I get my allowance." (Eng)

[...] kok udah datang kirimanku ku bayarlah. (Ind)

Context: Speech (39) is a speech by a third year junior high school student to a friend in front of dormitory. The speaker intended to promise to pay his friend back after his parents send him money.

(40)"[...] I'll come back later to pay the rest." (Eng)

[...] nanti saya datang lagi bayar kurangnya". (Ind)

Context: Speech (40) is a speech by a third year junior high school student to one of the vendors in canteen. He intended to promise to pay the rest of the money.

- Offering

(41) “[...] here, use my pen." (Eng)

[...] nah ini pakai pulpenku. (Ind)

Context: Speech (41) is a speech by a third year senior high school student to a friend in a class. The speaker's friend did not bring pen which caused him expelled from the class. The speaker felt sorry for him and offer his pen for his friend to use.

(42) “here, you want some?" (Eng)

"nah, mau?" (Ind)

Context: Speech (42) is a speech by a third year senior high school student to a friend in canteen. The speaker offered a food to eat together.

(43) "you can wear my slippers later." (Eng)

"nanti kamu pakai sandal saya saja". (Ind)

Context: Speech (43) is a speech by a third year junior high school student in dormitory. The student intended to offer his slippers to a friend who did not have ones.

\section{Expressive Speech Act}

Expressive speech act is a speech act that expresses the speaker's psychological attitude toward a situation, such as expressing gratitude, offering congratulations, forgiving, blaming, praising, offering condolences, etc. The speech act of expressing gratitude, forgiving, demeaning, praising, and blaming were found during this research. 
Proceedings of the $1^{\text {st }}$ Annual International Conference on Language and Literature, 18-19 April 2018, Fakultas Sastra, UISU, Medan, Indonesia.

- Expressing Gratitude

(44) "Thank you" (Eng)

"Terimakasih ya" (Ind)

Context: Speech (44) is a speech by a third year senior high school student to a friend in a class. He thanked his friend for offering him a pen.

(45) "Thank you. I think it's not that great. (Eng)

"Terimakasih. Biasa saja menurut saya" (Ind)

Context: Speech (45) is a speech by a third year senior high school student to a friend for praising the clothes that the speaker wore. The compliment was responded with speech (45) with the intention to stay humble.

- Forgiving

(46) "[...] That's okay." (Eng)

[...] ya udahlah ia gak apa-apa. (Ind)

Context: Speech (46) is a speech by a third year senior high school student to a friend who apologized for returning a book late.

- Demeaning

(47) "You must have no money that you ask me to go together, right?" (Eng)

"Kau pasti gak ada duit makanya ngajak-ngajak kan? (Ind)

Context: Speech (47) is a speech by a third year junior high school student to a friend in front of dormitory. The speaker made a demeaning comment toward the hearer when he was asked to go buying food together in canteen.

(48) "[...] You borrowed the book but you have no shame." (Eng)

[...] dah minjam gak tau diri kelen. (Ind)

Context: Speech (48) is a speech by a third year junior high school student to two friends in front of dormitory. The speaker made a demeaning comment toward the hearers after they returned a book late.

- Blaming

(49) "What am I supposed to do? The book's still with him but he's absent today, there's nothing I can do." (Eng)

"Kayak mana loh, masih sama dia, dia gak masuk sekolah, terus mau diapain". (Ind)

Context: Speech (49) is a speech by a third year junior high school student to a friend in front of a class. The speaker blamed his other friend when the hearer asked him to return a book he borrowed.

(50) "I couldn't finish all my homework because of you." (Eng)

"Gara-gara kelen tugasku belum siap semua" (Ind)

Context: Speech (50) is a speech by a third year junior high school student to a friend in front of a class. The speaker blamed the hearer for returning a book late which caused him can not finish his homeworks. 
(51) "What do I do? Why aren't you giving my Social Studies book back?" (Eng)

"Cemana ini, kok gak dikasih orang ini buku IPS ku". (Ind)

Context: Speech (51) is a speech by a third year junior high school student to a friend in front of a class. The speaker blamed the hearer for returning a book late which caused him can not finish his homeworks.

(52) "[...] why are you the one making a fuss?" (Eng)

[...] kok kau pulak sibuk. (Ind)

Context: Speech (52) is a speech by a third year junior high school student to a friend in front of a class. The speaker blamed the hearer for meddling in the speaker's business.

- Upset

(53) "See with your eyes, not your legs!" (Eng)

"Kalau jalan pakai mata jangan pakai dengkul" (Ind)

Context: Speech (53) is a speech by a third year senior high school student to a friend who accidentally stepped on his foot. The speech is intended to express the speaker's annoyance because he felt that his foot was stepped on by purpose.

\section{Politeness Strategy}

Politeness strategy of Dyah Galih Agung Senior and Junior High School students is closely related to the use of illocutionary act as already explained above. In line with this matter, it has also been emphasized in the beginning that language politeness is always related to the use of speech act (refer to Siregar, 2011: 97). This is because of in using a speech act, besides to express his purpose and wish, the speaker naturally intends to create and maintain a certain social relationship between the speaker and the hearer.

At the beginning of this research, the team heard from the students even the teachers that they have not heard at all about the strategy for language politeness which can be dug up, utilized, and developed from every language around the world. This fact is in line with Pranowo (2009:4) who stated that most of language users do not know yet that there is a politeness structure in a language structure.

Based on this matter, the team found out that the speech acts by Dyah Galih Agung Senior and Junior High School students in Deli Serdang District still can not be categorized as a polite language. This statement is made in accordance with Leech (2014) who said that it is language politeness when the speaker gives favor/benefit not only to himself but also the hearer and the third party whether the third party is present or not in the speech situation. This time, he symbolized the speaker by $S$ (self) and the hearer and the third party by $\mathrm{O}$ (other).

Supporting the statement above, some findings are presented as the illustration:

- Speech act of direct command

Contoh: Example:

(15) "hey, hey, come here, both of you[...]" (Eng) 
"eh, eh, sini dulu kelen dua[...] (Ind)

Context: Speech (15) above is a speech by a third year senior high school student to two third year junior high school students in front of dormitory with the intention to have the two students coming. In this speech, the speaker used the strategy of direct command indicated by imperative mood. Hence, speech (15) does not sound polite.

"[...]throw this rubbish!" (Eng)

"[...]buang dulu sampah ini!" (Ind)

Context: Speech (16) is a speech by a third year senior high school student to two third year junior high school students in front of dormitory with the intention to have them throwing the rubbish. In this speech, the speaker used the strategy of direct command indicated by imperative mood. Hence, speech (16) does not sound polite.

(17) "Get in there quickly!" (Eng)

"Cepat sana!" (Ind)

Context: Speech (17) is a speech by a third year senior high school student to a third year junior high school student in front of dormitory with the intention to make the the hearer not come late to the class. In this speech, the speaker used the strategy of direct command indicated by imperative mood. Hence, speech (17) does not sound polite.

(54) "Get that broom and sweep the floor." (Eng)

"Ambil sapu itu, sapukan terus" (Ind)

Context: Speech (54) is a speech by a third year senior high school student to a first year senior high school student to clean the dirty dormitory. In this speech, the speaker used the strategy of direct command indicated by imperative mood. Hence, speech (54) does not sound polite.

- Speech act of direct request

(19)"Just give it back to me." (Eng)

"Balikin pokoknya" (Ind)

Context: Speech (19) is a speech by a student who asked a friend to return a book. In this speech, the speaker used the strategy of direct command indicated by imperative mood. Hence, speech (19) does not sound polite.

(22) "Please teach me" (Eng)

"Ajari aku ya" (Ind)

Context: Speech (22) is a speech by a third year junior high school student to a friend who succeeded in presenting his homework in front of the class. The speaker wanted to ask the hearer to teach him about the homework.

(55) "Respect the students who cleaned the class." (Eng)

"Hargailah yang piket" (Ind)

Context: Speech (55) is a speech by a third year junior high school student to a friend who intentionally made a mess on the floor that had been cleaned by the speaker. 
Hence, the speaker intended to ask the hearer to give respect to him who had clean the floor.

- Speech act of expressing gratitude

(44) "Thank you" (Eng)

"terimakasih ya" (Ind)

Context: Speech (44) is a speech by a third year senior high school student to a friend in a class. The speaker thanked the hearer for offering him a pen. This speech is a polite speech because the hearer felt happy when his help is appreciated.

- Speech act of forgiving

(46) "[...] That's okay." (Eng)

[...] ya udahlah ia gak apa-apa. (Ind)

Context: Speech (46) is a speech by a third year senior high school student to a friend who apologized for returning a book late. This speech is a polite speech because the hearer felt that his apology is accepted.

- Speech act of bragging

(56) "My clothes are always nice everyday." (Eng)

"Memang bajuku cantik setiap hari" (Ind)

Context: Speech (56) is a speech by a third year junior high school student to a friend who praised the speaker for wearing nice new clothes. This speech intended to express the proud of the speaker for having and wearing nice new clothes which makes it sound impolite.

Regarding the findings above, the phenomena of the use of polite and impolite language will keep going on as long as people use language (refer to Pranowo, 2009: 56). The same happens among Dyah Galih Agung Senior and Junior High School students. Nevertheless, introducing and informing about language politeness could prevent them from saying harsh words which tend to trigger conflict and disharmony.

\section{The Effectiveness of Leech's Politeness Model (2014)}

Based on the result of the research and after giving understanding about the application of Leech's politeness model (2014) to all respondents, the fact shows that the students' polite speaking skill improved. The students who at first did not know about language politeness have known more about and are now able to apply Leech's politeness model (2014). This fact is supported by the data found during the research as follows:

(57) "Please throw the rubbish in its place so that our dormitory becomes clean." (Eng)

"Tolong ya sampahnya dibuang biar asrama kita bersih" (Ind)

Context: Speech (57) is a speech by a third year senior high school student to a third year junior high school student in front of dormitory with the intention to order the hearer to throw the rubbish in its place. In this speech, the speaker used NegPoliteness strategy by ordering through indirectness indicated by diction "please" and 
Proceedings of the $1^{\text {st }}$ Annual International Conference on Language and Literature, 18-19 April 2018, Fakultas Sastra, UISU, Medan, Indonesia.

"our" which represent inclusiveness. This speech is categorized as the realization of maxim of wisdom. Hence, speech (57) is categorized as a polite speech.

(58) "May I have some?" (Eng)

"Boleh aku minta sedikit?" (Ind)

Context: Speech (58) is a speech by a third year senior high school student to a third year junior high school student in front of dormitory with the intention to order the hearer to throw the rubbish in its place. In this speech, the speaker used NegPoliteness strategy by ordering through indirectness indicated by diction "may" and the use of interrogative mood. This speech is categorized as the realization of maxim of wisdom. Hence, speech (58) is categorized as a polite speech.

(59) "It's not that I don't want to lend you money, but I only have enough for myself, so maybe next time, l'm sorry." (Eng)

"Bukannya aku gak mau minjamkan, tapi uangku pun pas-pasan, lain kali saja ya, maaf ya". (Ind)

Context: Speech (59) is a speech by a third year junior high school student to a friend who borrowed money from him. The intention of the speech is to apologize because the speaker could not lend the hearer money. In this speech, the speaker used PosPoliteness strategy indicated by the phrase "maybe next time" which expresses the obligation of the speaker to lend some money next time. This speech is categorized as the realization of maxim of obligation. Hence, speech (59) is categorized as a polite speech.

(60) "I'Il get it for you when I come back from toilet." (Eng)

"Nanti saya kembali dari kamar mandi saya akan mengambilkannya". (Ind)

Context: Speech (60) is a speech by a third year junior high school student to a teacher who asked the speaker to get a book that was left in a class. The intention of the speech is to promise something. In this speech, the speaker used Pos-Politeness strategy indicated by the clause "I'll get it for you" which expresses the generosity of the speaker to get the book that was left in the class. This speech is categorized as the realization of maxim of generosity. Hence, speech (59) is categorized as a polite speech.

(61) "Congratulation, your presentation is so great." (Eng)

"Selamat ya presentasimu bagus sekali". (Ind)

Context: Speech (61) is a speech by a third year senior high school student to a friend who succeeded in presenting a homework in front of class. The intention of the speech is to offer congratulation. In this speech, the speaker used Pos-Politeness strategy indicated by the phrase "so great" which expresses the speaker's sympathy toward the hearer's performance. This speech is categorized as the realization of maxim of sympathy. Hence, speech (59) is categorized as a polite speech.

(62) "No, it's not that great." (Eng)

"Nggak ah biasa saja" (Ind) 
Context: Speech (62) is a speech by a third year senior high school student to a friend who praised the speaker for wearing nice new clothes. The intention of the speech is to stay humble. In this speech, the speaker used Pos-Politeness strategy indicated by the sentence "it's not that great" which expresses the speaker's modesty toward the hearer's compliment. This speech is categorized as the realization of maxim of modesty. Hence, speech (59) is categorized as a polite speech.

(63) "[...]you're more beautiful." (Eng)

"[...]yang bilangpun lebih cantik". (Ind)

Context: Speech (63) is a speech by a third year junior high school student to a friend who praised the speaker for wearing nice new clothes. The intention of the speech is to give praise. In this speech, the speaker used Pos-Politeness strategy indicated by the phrase "more beautiful" which expresses the speaker's compliment toward the hearer. This speech is categorized as the realization of maxim of praise. Hence, speech (59) is categorized as a polite speech.

(64) "Where is that thing you borrowed from me yesterday?" (Eng)

"Mana barangku yang kamu pinjam kemarin? (Ind)

Context: Speech (64) is a speech by a third year junior high school student to a friend in front of dormitory with the intention to ask for a stuff back. In this speech, the speaker used Neg-Politeness strategy by asking through indirectness indicated by diction "where" and the use of interrogative mood. This speech is categorized as the realization of maxim of wisdom. Hence, speech (57) is categorized as a polite speech.

(65) "Just wear my slippers for now." (Eng)

"Pakai sandalku saja dulu untuk sementara" (Ind)

Context: Speech (65) is a speech by a third year junior high school student to a friend who did not have slippers to go to a mosque. The intention of the speech is to offer something. In this speech, the speaker used Pos-Politeness strategy indicated by the sentence "just wear my slippers" which expresses the speaker's generosity to offer his slippers. This speech is categorized as the realization of maxim of generosity. Hence, speech (59) is categorized as a polite speech.

(66) "do you mind if I borrow your book?" (Eng)

"kalau tidak keberatan aku pinjam bukumu ya? (Ind)

Context: Speech (66) is a speech by a third year senior high school student to a friend who had a book that the speaker needed. The intention of the speech is to borrow something. In this speech, the speaker used Neg-Politeness strategy which is indicated by the word "if" as the hedging. The speech is also realized with interrogative mood by asking through indirectness. This speech is categorized as the realization of maxim of wisdom. Hence, speech (57) is categorized as a polite speech.

(67) "If I'm not mistaken, I've seen it." (Eng)

"Kalau tidak salah aku pernah lihat" (Ind) 
Proceedings of the $1^{\text {st }}$ Annual International Conference on Language and Literature, 18-19 April 2018, Fakultas Sastra, UISU, Medan, Indonesia.

Context: Speech (67) is a speech by a third year senior high school student to a friend who asked about something. The intention of the speech is to give opinion. In this speech, the speaker used Neg-Politeness strategy which is indicated by the word "if" as the hedging. This speech is categorized as the realization of maxim of opinion. Hence, speech (57) is categorized as a polite speech.

\section{Conclusion}

The speech of Dyah Galih Agung Senior and Junior High School students can be classified into assertive, directive, expressive, and commissive speech act. There is no declarative speech act used by the students. The students use direct speech act more than indirect speech act. This is because they have already felt close to each other so they choose to use direct speech act. Leech's politeness model (2014) is an effective solution and way to improve the polite speaking skill of Dyah Galih Agung Senior and Junior High School students in Deli Serdang District.

\section{References}

Arikunto, Suharsimi, dkk. (2006). Penelitian Tindakan Kelas. Jakarta: Bumi Aksara.

Austin, J.L. (1962). How to Do Things With Words. London: Cambridge University Press.

Baryadi, Praptomo. (2012). Bahasa, Kekuasaan, dan Kekerasan. Yokyakarta: Universitas Sanata Dharma.

Cruse, Alan. (2006). A Glossary of Semantics and Pragmatics. Edinburgh: Edinburgh

Griffiths, Patrick. (2006). An Introduction to English Semantics and Pragmatics. Edinburgh: Edinburgh University Press.

Holmes, Janet dan Maria Stubbe. (2015). Power and Politeness in the Workplace: a Sociolingusitic Analysis of Talk at Work. New York: Routledge.

Kridalaksana, Harimurti. (2008). Kamus Linguistik. Jakarta Gramedia.

Kusno, Ali. (2014). Kesantunan Bertutur Oleh Orang Tua Kepada Anak Di Lingkungan Rumah Tangga. Dinamika Ilmu. Vol. 14 (1), 13-25.

Leech, Geofrey. (1983). Priciples of Pragmatics. New York: Longman.

Leech, Geofrey. (2014). The Pragmatics of Politeness. New York: Oxford University Press.

Miles, Matthew. B dan A. Michael Huberman. (1992). Analisis Data Kualitatif (edisi terjemahan oleh Tjetjep Rohendi Rohidi). Jakarta: UI-Press.

Pranowo. (2009). Berbahasa Secara Santun. Yogyakarta: Pustaka Pelajar.

Purwo, Bambang Kaswanti. (1990). Pragmatik dan Pengajaran Bahasa. Yogyakarta: Kanisius.

Sani, Ridwan Abdullah dan Sudirman. (2012). Penelitian Tindakan Kelas. Bandung: Citapustaka Media Perintis.

Sari, Reni Novita dan Ivan Muhammad Agung. (2015). Pemaafan dan Kecenderungan Perilaku Bullying pada Siswa Korban Bullying. Jurnal Psikologi. Vol. 11 (1), 32-36

Searle, John R. (1979). Expression and Meaning: Studies in The Theory of Speech Act. Cambridge: Cambridge University Press.

Sibarani, Robert. (2014). Pembentukan Karakter: Langkah-langkah Berbasis Kearifan Lokal. Jakarta: Asosiasi Tradisi Lisan. 
Proceedings of the $1^{\text {st }}$ Annual International Conference on Language and Literature, 18-19 April 2018, Fakultas Sastra, UISU, Medan, Indonesia.

Siregar, Bahren Umar. (2011). Seluk-Beluk Fungsi Bahasa. Jakarta: Pusat Kajian Bahasa dan Budaya Universitas Katolik Indonesia Atma Jaya.

Suprihatin, Bambang. (2012). Hubugan Intensitas Menonton Tayangan Kekerasan di Televisi dan Intensitas Pemberian Punishment dengan Perilaku Bullying di Kalangan Pelajar SMA. Journal of Educational, Health and Community Psychology. 1 (1), 76-86.

Tarigan, Henry Guntur. (1990). Pengajaran Pragmatik. Bandung: Angkasa.

Thornbury, Scott. (1989). How to Teach Speaking. New York: Longman.

Widdowson, H.G. (19960. Teaching Language as Communication. New York: Oxford University Press.

Wijana, I Dewa Putu dan Muhammad Rohmadi. (2009). Analisis Wacana Pragmatik: Kajian Teori dan Analisis. Surakarta: Yama Pustaka.

Wiriaatmadja, Rochiati. (2008). Metode Penelitian Tindakan Kelas. Bandung: Remaja Rosdakarya. 